\title{
Enhancing the Role of the District Government in Decentralized Forest Management
}

\author{
Ristianto Pribadi ${ }^{1}$, Dodik Ridho Nurrochmat ${ }^{2 *}$ Endang Suhendang ${ }^{2}$, Hermanto Siregar $^{3}$ \\ 'Graduate School in Forest Management Science, Faculty of Forestry and Environment, IPB University, Academic Ring Road, \\ Campus IPB Dramaga, Bogor, Indonesia 16680 \\ ${ }^{2}$ Department of Forest Management, Faculty of Forestry and Environment, IPB University, Academic Ring Road, Campus IPB \\ Dramaga, Bogor, Indonesia 16680 \\ ${ }^{3}$ Department of Economics, Faculty of Economics and Management, IPB University, Academic Ring Road, Campus IPB \\ Dramaga, Bogor, Indonesia 16680
}

Received November 14, 2019/Accepted July 6, 2020

\begin{abstract}
Following the enactment of Law Number 23 of 2014 on the Regional Government, which superseded Law Number 22 of 1999 and Law Number 32 of 2004, now the local government has no longer holds an authority to manage state forest areas, except "grand forest park" (Taman Hutan Raya) located in their respective administrative areas. The management of production forests and protected forests (located at state forest areas) is the authority and responsibility of the provincial government, while the management of conservation forests is the authority of the central government. The success of forest management and management program activities is determined, among others, by government and local government policies and their implementation at the site level. By considering ntthe complexity of forest management, the context of decentralization, and available resources as well as constrained authority, this study aims to identify the level of importance, priorities, and main roles of district governments in forest management by applying the analytic network process (ANP) method. This study suggests that the district government could play a significant role in building social capital, which serves as a first step in developing collaborative forest management by promoting the optimization of multipurpose forests to preserve forests.
\end{abstract}

Keywords: analytic network process, decentralized forest management, government role, social capital

*Correspondence author, email:dnurrochmat@apps.ipb.ac.id

\section{Introduction}

Decentralization has become a global phenomenon affecting many developing countries, including Indonesia (Nurrochmat, 2005; Ribbot \& Larson, 2005). In the early 2000 s, when the decentralization just commenced in Indonesia, the World Bank (2003) classified Indonesia as a very decentralized country in terms of the portion of regional expenditure, where local governments were responsible for one-third of the country's total expenditure and half of the development budget. Since then, there has been an increased interest in looking at the role of local governments.

As the decentralization process continued, the country has passed through several phases. These phases have been accompanied by an amendment in the regulatory frameworks that affect the distribution of authority between central and local governments. In the late 1990s, for instance, Law Number 22 of 1999 on the Regional Government was enacted. The Law was then revised by Law Number 32 of 2004, then later by Law Number 23 of 2014. As stipulated in Article 14 of Law Number 23 of 2014, the local government has no more extended authority to manage state forest areas except "grand forest parks" (Taman Hutan Raya) in their respective administrative areas. The explanation part of Law Number 23 of 2014 further stated that the management of state forest areas including production and protected forests lie within the authority and responsibility of the provincial government, while the central government holds the authority to manage conservation forests (Nurrochmat et al., 2017; Harbi et al., 2018). A key policy question is how this distribution of authority is influencing the rate of deforestation.

A case study in Tebo District in Jambi Province shows that the deforestation rates are increased in the early 2000s, before reaching its peak in 2013 (Figure 1). A decreasing trend has been observed since the issuance of the latest Regional Government Law in 2014. However, no data or information is stating that the decline in deforestation rates in Tebo District during this period is linked to the implementation of forestry decentralization.

Moreover, nowadays there is no clear directions or policies whether the local government can still have a role in achieving the objectives mandated by Law Number 41 of 1999 on Forestry. Those objectives are (1) ensuring the 
$90,000.000$

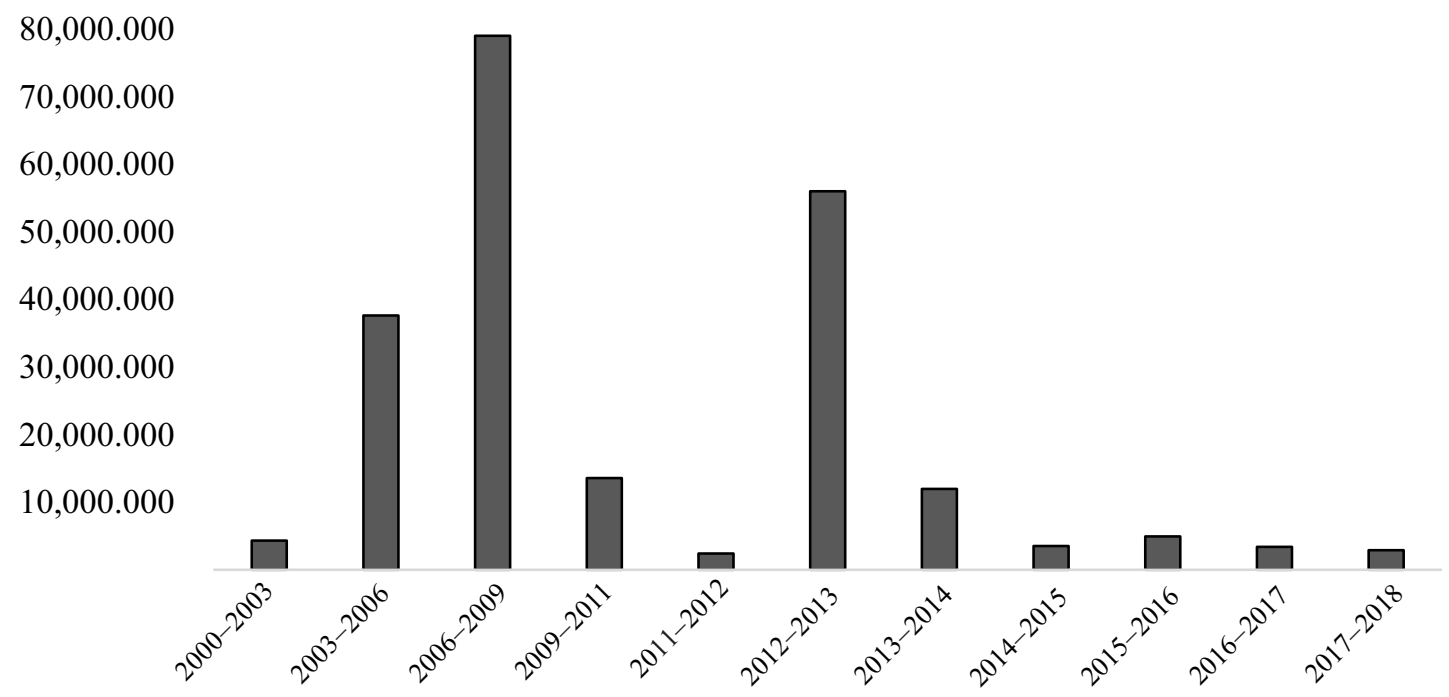

Source: Directorate General of Forestry Planning and Environmental Governance.

Figure 1 Rate of deforestation (hectare/year) in Tebo District, Jambi Province.

existence of forests with sufficient areas and proportional distribution; (2) optimizing various forest functions including conservation, protection and production functions to achieve balanced and sustainable environmental, social, cultural and economic benefits; (3) increasing the carrying capacity of watersheds; (4) increasing the ability to develop community capacity and empowerment in a participatory, fair and environmentally sustainable manner in order to create social and economic resilience and resilience to the consequences of external change; and (5) ensuring equitable and sustainable distribution of benefits.

This study aims to identify the level of importance, priorities, and main roles of district governments in forest management by applying the analytic network process (ANP) method.

\section{Methods}

This study focuses on Tebo District, Jambi. The district has an area of $646,100 \mathrm{ha}\left(6,461 \mathrm{~km}^{2}\right)$ or $12.88 \%$ of the total area of Jambi Province (PEMKAB Tebo, 2017). Growing at an average of $2 \%$ per year, the population of Tebo District in 2017 was 343,003. By 2017, Tebo District's gross regional domestic product stood at nearly IDR 13 trillion, about half of which came from the agriculture, forestry, and fisheries sector (Tebo Statistical Agency (BPS) 2018). Forest areas occupy $43.33 \%$ (280,100 ha) of the Tebo District's total area. This represents $13.32 \%$ of the Jambi Province's total state forest areas $(2,102,840$ ha) (Forestry Service Office/DISHUT Jambi, 2015). As part of this study, data collection activities were conducted between December 2018 and March 2019 in Tebo District, Jambi Province.

This study conducted three stages of data collection. The first stage was a content analysis to review three planning documents, namely:

(1) Ministry of Environment and Forestry Strategic Plan for
2015-2019 (KLHK, 2015)

(2) Strategic Plan for Jambi Province Forestry Service 20162021 (DISHUT Jambi, 2016)

(3) Medium-term Development Plan of Tebo District in 2017-2022 (PEMKAB Tebo, 2017)

The Ministry of Environment and Forestry Strategic Plan Year 2014-2019 provides a list of programs and activities, barriers, basic capitals, goals, and financial framework for achieving the Ministry's vision. Furthermore, the Jambi Provincial Forestry Service Year Strategic Plan Year 20162021 is covering the main duties and authorities of the Jambi Provincial Forestry Service in managing state forests, mainly production and protection forests, as well as describing the vision, mission, strategic issues, problems and a list of activity programs for achieving the development goals of the Jambi forestry sector. Meanwhile, the Tebo District Medium-Term Development Plan Year 2017-2022 is providing direction to regional financial policies and development strategies. It also functions as a guideline to ensure consistency between planning, budgeting, implementation, and supervision of Tebo's development programs. The document is chosen given that forestryspecific planning document for the Tebo District is nonexistent. In brief, those three documents were selected to describe the forest management policy chain from the national, provincial to district levels. Results from this stage informed the concept of clusters and elements of forestry development in Tebo District, Jambi.

The second stage comprised of focus group discussions with six selected expert respondents, representing the Tebo District Regional Development Planning Agency, the Jambi Provincial Forestry Office, Jambi University, the Jambi Natural Resources Conservation Agency, and Jambi forestry senior observers. The selection of focus group discussion (FGD) participants were based on their expertise and 
understanding of both local development and forest management in the Tebo District. While this selection basis narrowed down the number of experts relevant to the research theme, information derived from the FGD is comprehensive and provides further consideration to the establishment of clusters and development elements obtained in the previous stage. The Indonesian national language (Bahasa Indonesia) was used during the FGDs to ensure that there was no language barrier.

In the third stage, a questionnaire with 685 questions adjusted to the requirements of the analysis tool used were developed. Individual interviews with six selected expert respondents were then held using this questionnaire.

The collected data is analyzed using the ANP technique. The ANP is a mathematical theory that enables a decisionmaker to deal with various interconnected (dependent) factors and develop systematical feedback. The ANP can also be used to assess the level of importance of various stakeholders by taking into account the relationship of dependence elements, both between criteria and sub-criteria (Saaty, 2005), as well as a new alternative approach for qualitative studies that can combine intangible values and subjective assessments with statistical data and other tangible factors (Saaty \& Vargas, 2006). This method is used in the form of resolution with consideration of adjusting the complexity of the problem accompanied by the scale of priorities that produce the most significant priority effect. The ANP components consist of a hierarchy of controls, clusters, elements, relationships between elements, and relationships between clusters. There are two types of linkages in the ANP method, namely the linkages in a set of elements (inner dependence) and the relationships between different elements (outer dependence).

\section{Results and Discussion}

Elements and clusters of forestry development in Tebo District, Jambi This study categorized four clusters and related elements of forestry development in Tebo District, Jambi, based on FGD with six expert respondents (Table 1). However, for the first cluster 'Purposes of Forestry Management' refers to objectives outlined in Article 3 of Law Number 41 of 1999 concerning Forestry.

According to FGDs, Figure 2 presents dependency relationships between the four clusters and elements as represented by two-way arrows. This ANP structure is not linear and instead represents a cycle network comprised of interrelated clusters and elements. Based on the ANP in Figure 2, responses to 685 questionnaire questions were then collected from the six respondent experts. The analysis then involved setting weighting criteria and weighting of dependencies between criteria using paired comparison matrices. The analysis is carried out by assessing the importance level of each criterion comparison that assessed by the six respondent experts. Scales 1 to 9 are used for pairwise comparisons.

Results from the data collection stages were then processed using Super Decision ANP software version 3.2.0. The software is widely used in the analysis for deciding the most priority parameter. Table 2 presents the level of priority of elements in each cluster resulted in the ANP technique.

The priority elements are those with the highest weighting values in each cluster. In the Purposes of Forestry Management cluster, the priority element is the optimization of the multiple uses of a forest with a weight of 0.24493 . Meanwhile, for social capital with a weight of 0.20819 ; the government of district (0.30266); and multi-stakeholder involvement in development $(0.24530)$ are identified as

Table 1 Clusters and elements of forestry development in Tebo District, Jambi

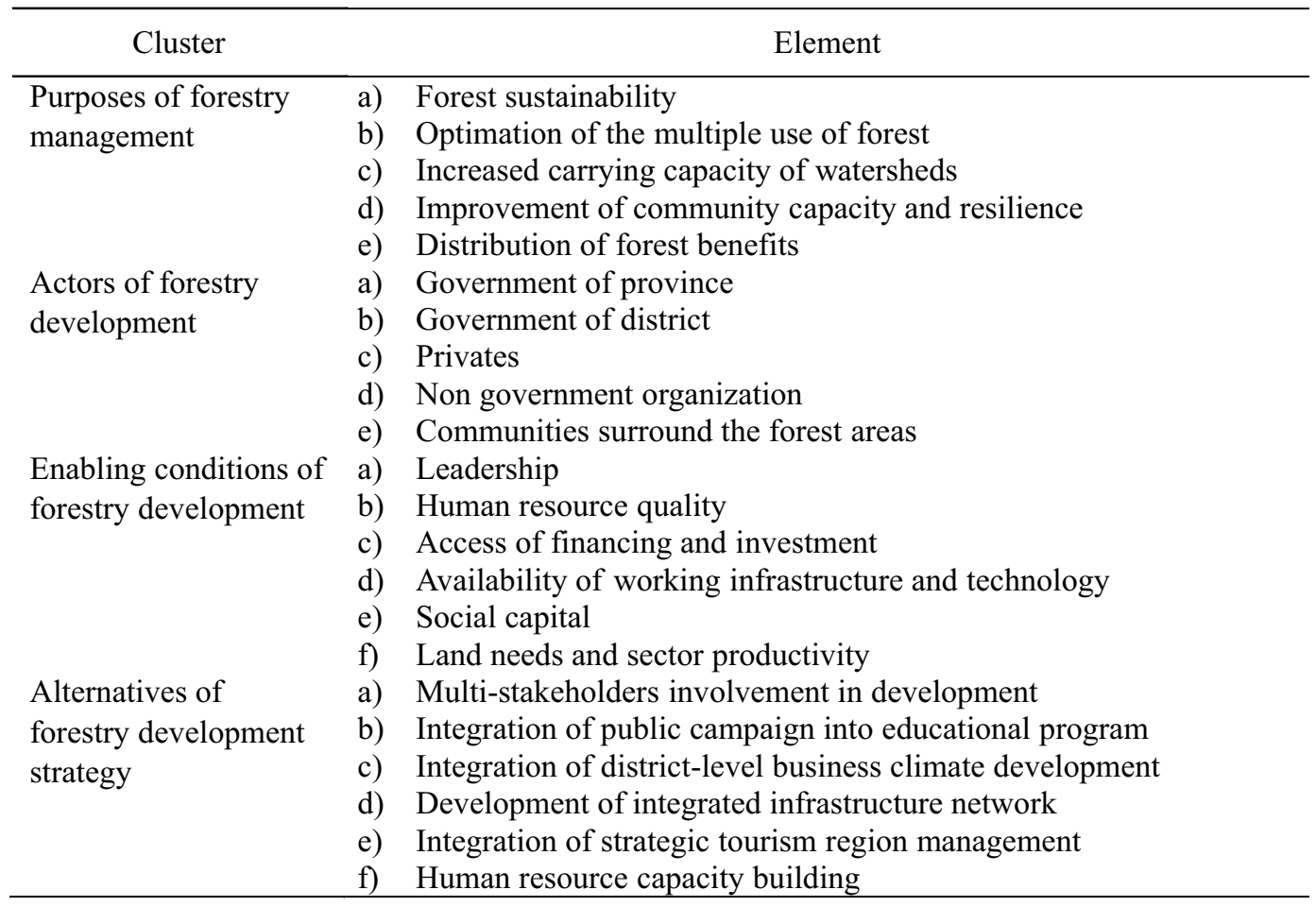




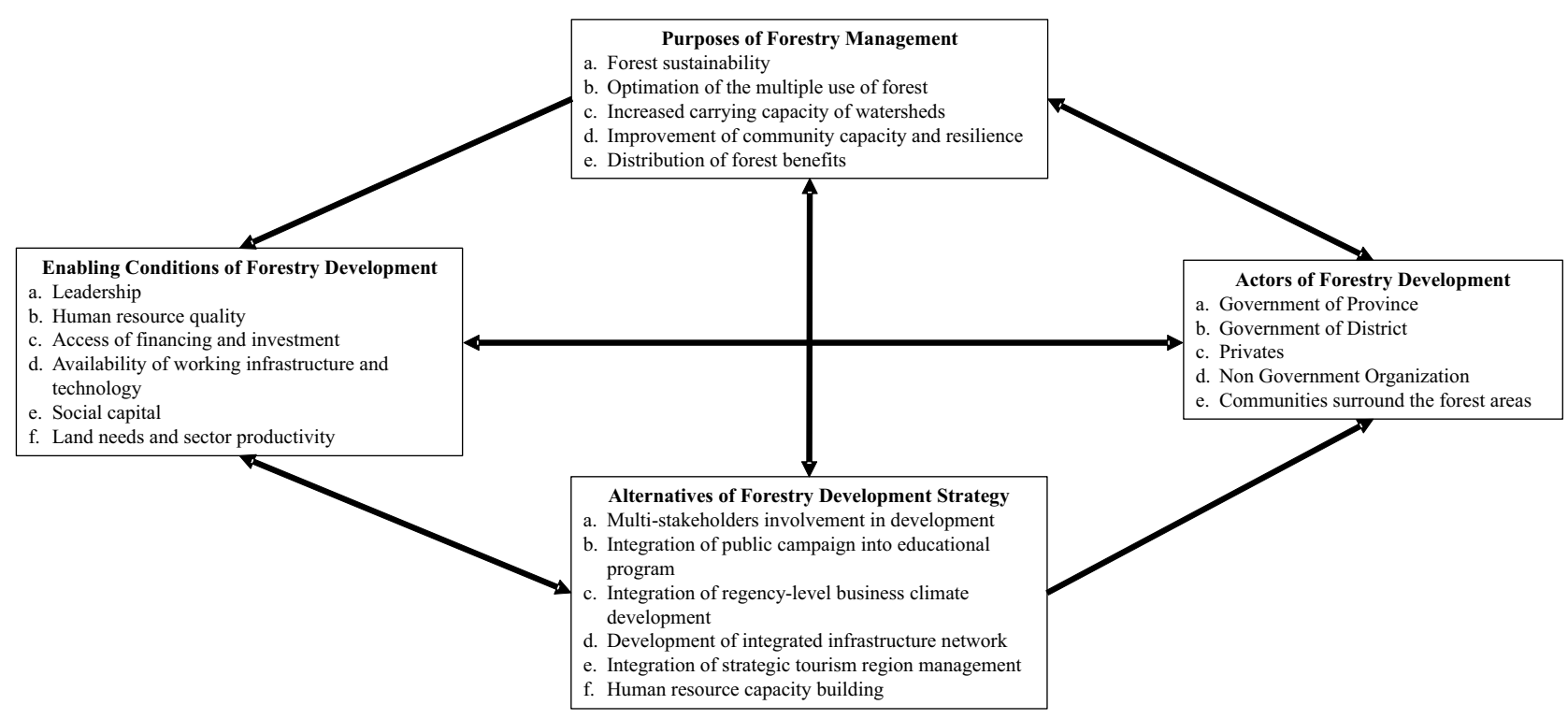

Figure 2 ANP model structure for selecting the roles and priorities of the Tebo District government in supporting forestry development.

Table 2 The level of priority of elements in each cluster

\begin{tabular}{|c|c|c|}
\hline Cluster & Element & Weight \\
\hline \multirow{5}{*}{$\begin{array}{l}\text { Purposes of forestry } \\
\text { management }\end{array}$} & Optimization of the multiple uses of forest & 0.24493 \\
\hline & Forest sustainability & 0.20992 \\
\hline & Distribution of forest benefits & 0.20218 \\
\hline & Increased carrying capacity of watersheds & 0.17593 \\
\hline & Improvement of community capacity and resilience & 0.16703 \\
\hline \multirow{6}{*}{$\begin{array}{l}\text { Enabling conditions of forestry } \\
\text { development }\end{array}$} & Social capital & 0.20819 \\
\hline & Human resource quality & 0.18206 \\
\hline & Leadership & 0.16839 \\
\hline & Availability of working infrastructure and technology & 0.15212 \\
\hline & Access of financing and investment & 0.15040 \\
\hline & Land needs and sector productivity & 0.13884 \\
\hline \multirow[t]{5}{*}{ Actors of forestry development } & Government of district & 0.30266 \\
\hline & Government of province & 0.28048 \\
\hline & Communities surround the forest areas & 0.17535 \\
\hline & Non government organization & 0.12086 \\
\hline & Privates & 0.12065 \\
\hline \multirow{6}{*}{$\begin{array}{l}\text { Alternatives of forestry } \\
\text { development strategy }\end{array}$} & Multi-stakeholders involvement in development & 0.24530 \\
\hline & Human resource capacity building & 0.18682 \\
\hline & Integration of integrasi district-level business climate & 0.16171 \\
\hline & Development of integrated infrastructure network & 0.15265 \\
\hline & Integration of strategic tourism region management & 0.13800 \\
\hline & Integration of public campaign into educational program & 0.11553 \\
\hline
\end{tabular}


priority elements in the enabling conditions, actors, and alternative strategy of forestry development, respectively.

Priority and importance of district governments in supporting forestry development Noting the importance of the district government, which serves as the priority element in the 'Actors' cluster, Table 3 lists down results from the ANP technique on the district's government priorities in achieving the purposes of forestry management (the 'Purposes' cluster). Out of the five purposes being assessed, the optimization of the multiple uses of a forest shows the highest weight indicating the high priority of this element for the district government. Furthermore, Table 4 looks at the district government's priority in achieving the enabling conditions of forestry development and suggests social capital as the highest priority. Those findings are in line with Sahide et al. (2015) and Maryudi et al. (2018).

The ANP analysis carried out in this study also identifies the district government's priority for the implementation of alternative development strategies (the 'Alternative Strategy' cluster), as shown in Table 5 .

Several alternative development strategies following the district government's authority are considered, namely: integration of district-level business climate development (Di Gregorio et al. 2016; 2019); multi-stakeholder involvement in the process of planning and implementing

Table 3 District government's priority in achieving the purposes of forestry management

\begin{tabular}{lc}
\hline Element & Weight \\
\hline Increased carrying capacity of watersheds & 0.211 \\
Distribution of forest benefits & 0.189 \\
Improvement of community capacity and resilience & 0.160 \\
Forest sustainability & 0.124 \\
Optimation of the multiple use of forest & $\mathbf{0 . 3 1 7}$ \\
\hline
\end{tabular}

Source:ANP result district development plans (Nurrochmat et al., 2016a; Erbaugh et al., 2017; Budiono et al. 2019); integration of management of strategic tourism areas; integration of public campaigns in basic education programs, early childhood education and non-formal education; and increasing the capacity of human resources in the field of environmental management and biodiversity in an integrated manner. While Table 5 highlights the different weights between these elements with "integration of strategic tourism region management" having the highest weight, the differences in these elements' weights are minimal.

Next, the study looks at the district government's priority in creating enabling conditions (the 'Enabling Conditions' cluster), as shown in Table 6. Relevant elements include access to finance and investment, land requirements and sector productivity; quality of human resources; and social capital. Furthermore, based on five forestry implementation objectives mandated by Law Number 41 of 1999 on Forestry, ANP results presented in Table 7 identify those district governments have the highest level of importance for achieving forest sustainability goals.

The roles of district governments Based on the ANP analysis of the relationship between elements of the district government and other elements, there is one element that has a high degree of importance in both directions, namely the

Tabel4 District government's priority in achieving the enabling conditions of forestry development

\begin{tabular}{ll}
\hline Element & Weight \\
\hline Access of financing and investment & 0.163 \\
Land needs and sector productivity & 0.129 \\
Availability of working infrastructure and technology & 0.129 \\
Human resource quality & 0.187 \\
Leadership & 0.166 \\
Social capital & $\mathbf{0 . 2 2 7}$ \\
\hline
\end{tabular}

Source: ANP result

Table 5 District government's priority for the implementation of development strategy alternatives

\begin{tabular}{lccccc}
\hline Element & $\begin{array}{c}\text { Integration of } \\
\text { district-level } \\
\text { business } \\
\text { climate } \\
\text { development }\end{array}$ & $\begin{array}{c}\text { Multi-stakeholders } \\
\text { involvement in } \\
\text { development }\end{array}$ & $\begin{array}{c}\text { Integration } \\
\text { of strategic } \\
\text { tourism } \\
\text { region } \\
\text { management }\end{array}$ & $\begin{array}{c}\text { Integration of } \\
\text { public campaign } \\
\text { into educational } \\
\text { program }\end{array}$ & $\begin{array}{c}\text { Human resource } \\
\text { capacity building }\end{array}$ \\
\hline Weight & 0.371 & 0.295 & 0.384 & 0.325 & 0.355 \\
\hline Source: ANPresult
\end{tabular}

Table 6 District government's priority in achieving the enabling condition

\begin{tabular}{cccc}
\hline Element & $\begin{array}{c}\text { Access of financing and } \\
\text { investment }\end{array}$ & $\begin{array}{c}\text { Human resource } \\
\text { quality }\end{array}$ & Social capital \\
\hline Weight & 0.320 & 0.272 & 0.321 \\
\hline Source:ANP result & & &
\end{tabular}


element of social capital. Putnam (1993) stated that social capital is a network, norms, and social trust that facilitate cooperation and coordination for mutual benefits, which can be measured by the amount of trust and reciprocity in a society or among individuals. In this study, social capital has the highest level of importance (priority) for district governments to create enabling conditions, as shown in Table 4.

Likewise, the district government has the highest level of interest compared to other elements of actors (provincial government, companies, NGOs, and communities around forests) to strengthen social capital within the framework forestry development (Table 6)

This finding is in line with existing studies that suggest that the success of development programs in the community, including forestry development programs, is not only influenced by the substance of the program but also by the strength of social capital in the community (Nurrochmat et al., 2016a). This difference in the levels of social capital is argued to explain why a program could be successfully implemented in one community but failed in others. Nurrochmat et al. (2016b), who modified the approach by Birner and Wittmer (2000), suggested that, theoretically, strengthening social capital would potentially reduce the cost of managing natural resources, as illustrated in Figure 3.

The Governance Cost (GC) curve shows that without cooperation in natural resource management, the government must cover a fixed cost of $\mathrm{C}$ and increasing

Table 7 District government's priority in achieving the purposes of forestry management

\begin{tabular}{cc}
\hline Element & Forest sustainability \\
\hline Weight & $\mathbf{0 . 3 9 4}$ \\
\hline
\end{tabular}

Source: ANP result additional costs as the care intensity level ( $\mathrm{x}$-axis) goes higher. The GC3 curve shows the pattern of expenditure if cooperation in natural resource management is carried out together between the government and the community (i.e., co-management). The initial costs will increase from $\mathrm{C}$ to $\mathrm{C} 3$, but over time as the broader scope of natural resources being managed (more care intensity), the cost of this comanagement will be more efficient.

In many cases, the management of forest resources by the government (i.e., state management) is a logical choice because it is perceived as more efficient, especially when the required resource management scope is not too broad, hence less care intensity. However, as resource management involves more complexity (i.e., more care intensity), comanagement could serve as a more efficient option than the state management, as shown by GC1' and GC2" curves (Figure 3).

To promote co-management in forestry development, a solid understanding of the processes involved in comanagement is important. Co-management covers various levels of integration and division of power between local community and government resource management systems (Erbaugh \& Nurrochmat, 2019). Such levels start from the process of government consultations with community groups, the process of delivering input into the government management system, to the management of user groups with government assistance (Pomeroy \& Berkes, 1997). Development of co-management depends on the nature of the boundaries of objectives within and between community groups and the government (Innes \& Booher 1999; Maryudi et al., 2018). Moreover, according to Habermas (1981), to build cooperation, efforts to understand rational communication are required. Decisions should generally be made through consensus between all stakeholders who are equally empowered, given complete information with statements that can be understood or logical, scientifically correct, and submitted by representatives of stakeholders (Nurrochmat et al., 2017).

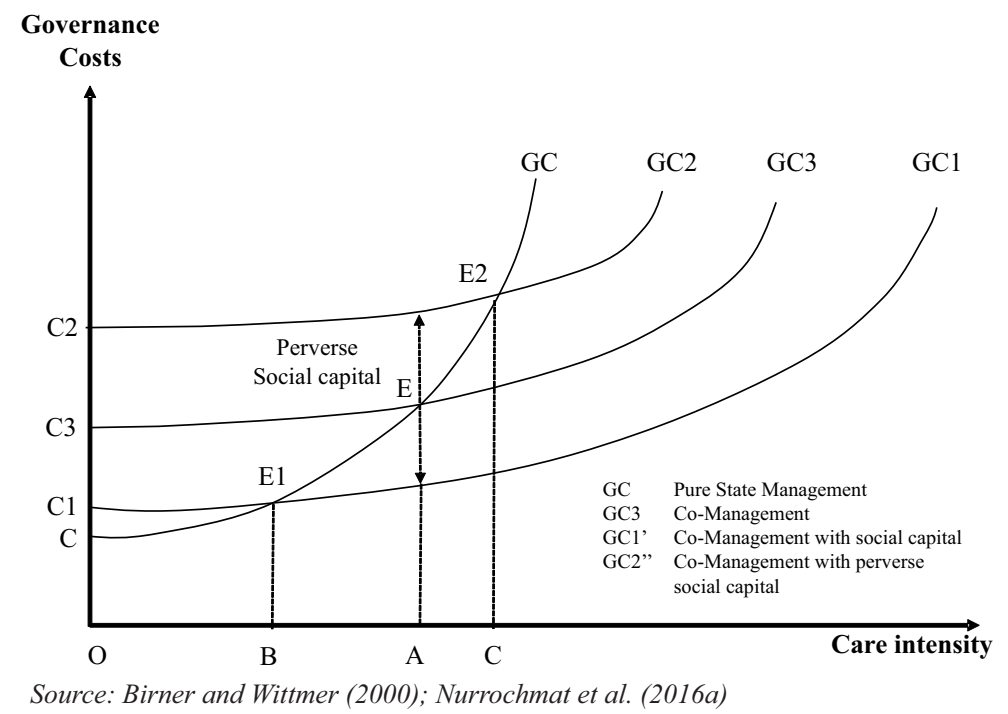

Figure 3 Effects of social capital on the costs of managing natural resources. Source: Birner and Wittmer (2000); Nurrochmat et al. (2016b). 
In the context of forestry development in Tebo District, Jambi, the Government of Tebo District can develop a program of activities to increase social capital that is focused on fostering mutual trust among community members, building networks, developing communication systems and improving coordination between leaders and community members, and among community members. Furthermore, the co-management of forest resources in the Tebo District can be developed between managers of state forest areas and communities surrounding the forests. Following Law Number 23 of 2014, the provincial government has the authority to manage Protection Forests and Production Forests through the Forest Management Unit (KPH), and the Ministry of Environment and Forestry (KLHK) for the management of Conservation Forests (Rochmayanto et al., 2019; Santoso et al., 2019). The Tebo District Government can play a role in bridging communication between the Jambi Provincial Government and KLHK and the communities surrounding the forest areas. Such a role is also aligned with the authority and development targets of the Tebo District Government, as defined in their Regional Mid-Term Development Plan (RPJMD).

One of the main aspects that should be addressed when building partnerships through co-management is how to achieve forestry implementation objectives as mandated by Law Number 41 of 1999 concerning Forestry. Based on the results of the analysis in this study, the district government has the highest level of importance (priority) in the element of optimization the multiple uses of forest contained in the forestry implementation cluster (Table 3 ) and the district government has the highest level of interest compared to other elements of the actors (provincial government, company NGOs, and communities around the forest) to achieve forest sustainability (Table 7).

Tampubolon et al. (2018) conveyed the notion of the multiple uses of the forest as an effort to manage all resources in the area of a forest management work unit so that it can be utilized in a combination that is most suitable for public needs. Moreover, the term is used wisely to provide sufficient space for a certain period. Therefore, the user is following changing needs and certain conditions; and managed in a harmonious and coordinated manner, without a decrease in productivity. Nevertheless, based on consideration of the value of the resource, it may not necessarily provide the greatest financial benefit value or the largest output unit (Nurfatriani et al., 2015).

The multiple uses of forest management (MFM) offer a complementary approach to the concept of sustainable forest management by emphasizing fairness across generations in the use of forest resources. It aims to use resources more equitably and equally among current forest resources users, as well as to increase the economic value of forests associated with joint exercises of various uses (Wang \& Wilson, 2007). From the MFM's point of view, the maintenance of long-term natural capital remains a goal; however it is a secondary objective to increase the benefits of current forest use and share it more equitably among different user groups (GarciaFernàndez et al., 2008; Sabogal et al., 2013).

The MFM is vital to be optimized considering the current increasing demands of the community for forests, both for wood and non-timber products and ecosystem services as well as increasing environmental and social awareness about tropical forests affecting the use of tropical forests (Sabogal et al., 2013; Sukwika et al., 2016). They further stated that under the right conditions, MFM could diversify forest use, increase forest productivity, and provide incentives to maintain forest cover. MFM can also increase the number of stakeholders, particularly in the Tebo District, that can receive forest benefits, which means expanding opportunities to develop co-management of forest resource management, which will ultimately lead to forest preservation and community welfare.

\section{Conclusion}

The application of the ANP method allows identification of priorities, importance levels, and the central role of district governments in supporting forestry development in the era of decentralization under Law Number 23 of 2014. Based on the study, the ANP analysis suggests that the district government puts highest priorities on two elements, namely the optimization of the multiple uses of forest in the cluster of forest management purposes and social capital in the cluster of enabling conditions for forestry development. Furthermore, the district government has a high level of importance compared to other elements of actors (provincial government, companies, NGOs, and communities around the forest) to play a role in the implementation of several alternative development strategies, namely: integration of district-level business climate development; multistakeholder involvement in the process of planning and implementing district development plans; integration of management of strategic tourism areas; integration of public campaigns in basic education programs, early childhood education and non-formal education; and increasing the capacity of human resources in the field of environmental management and biodiversity in an integrated manner. The district government is also perceived to play a role in realizing several elements of enabling conditions, namely access to finance and investment; land requirements and sector productivity; quality of human resources; and social capital, and play a role in preserving forests as part of the objectives of forestry operations.

\section{Recommendations}

The study points out the importance of the Tebo District government to build social capital and promote multiple-use forest management. Social capital serves as a priority element of enabling conditions for forestry development and could serve as a first step in developing co-management of forest resource management by promoting the optimization of multiple-use of forest management. This concept of multiple uses of the forest will broaden choices of activities that can be carried out by parties within the state forest area, as well as increase the number of parties who can benefit from the forest. To this end, under the current regulatory frameworks, while the provincial government and KLHK can analyze, refine and develop existing multiple uses of forest management policies, the Tebo District Government can play a role in bridging communication between the Jambi Provincial Government and KLHK and the communities around the forest areas. 


\section{Acknowledgment}

The authors would like to thank the Ministry of Environment and Forestry of the Republic of Indonesia for financing this study, to DIPI-LPDP for data and some financial support, and to Dr. Risti Permani of Deakin University Australia for her contributions in English proof.

\section{References}

Birner, R., \& Wittmer, H. (2000). On the "Efficient Boundary of the State." A Transaction Cost Economics Approach to the Analysis of Decentralization and Devolution in Natural Resources Management. In: The XXIV International Conference of Agricultural Economist. Berlin.

Budiono, R., Nugroho, B., Hardjanto., \& Nurrochmat, D. R. (2019). The village forest as a counter territorialization by village communities in Kampar Peninsula Riau. Jurnal Manajemen Hutan Tropika, 24(3), 115-125. https://doi.org/jtfm.24.3.115

Di Gregorio, M., Fatorellia, L., Paavolaa, J., Locatelli, B., Pramova, E., Nurrochmat, D. R., ..., \& Kusumadewi, S. D. (2019). Multi-level governance and power in climate change policy networks. Global Environmental Change, 54, 64-77. https://doi.org/10.1016/j.gloenvcha.2018.10. 003

Di Gregorio, M., Nurrochmat, D. R., Paavolaa, J., Sari, I. M., Fatorellia, L., Pramova, E., ..., \& Kusumadewi, S. D. (2016). Climate policy integration in the land use sector: Mitigation, adaptation and sustainable development linkages. Environmental Science \& Policy, 67, 35-43. https://doi.org/10.1016/j.envsci.2016.11.004

[DISHUT Jambi] Dinas Kehutanan Provinsi Jambi. (2016). Rencana strategis Dinas Kehutanan Provinsi Jambi 2016-2021. Jambi: Dinas Kehutanan Provinsi Jambi.

Erbaugh, J. T., Nurrochmat, D. R., \& Purnomo, H. (2016). Regulation, formalization, and smallholder timber production in northern Central Java, Indonesia. Agroforestry System, 91(5), 867-880. https://doi.org/10. 1007/s10457-016-0037-6

Erbaugh, J. T., \& Nurrochmat, D. R. (2019). Paradigm shift and business as usual through policy layering: Forestrelated policy change in Indonesia (1999-2016). Land Use Policy, 86, 136-146. https://doi.org/10.1016/ j.landusepol.2019.04.021

Garcia-Fernàndez, C., Ruiz, Pérez M., \& Wunder, S. (2008). Is multiple-use forest management widely implementable in the tropics? Forest Ecology Management 256, 1468-1476. https://doi.org/10.1016/ j.foreco.2008.04.029

Harbi, J., Erbaugh, J. T., Sidiq, M., Haasler, B., \& Nurrochmat, D. R. (2018). Making a bridge between livelihoods and forest conservation: Lessons from non timber forest products' utilization in South Sumatera,
Indonesia. Forest Policy and Economics, 94, 1-10. https://doi.org/10.1016/j.forpol.2018.05.011

[KLHK] Kementerian Lingkungan Hidup dan Kehutanan. (2015). Rencana strategis Kementerian Lingkungan Hidup dan Kehutanan Tahun 20152019. Jakarta: KLHK.

Maryudi, A., Nurrochmat, D. R., \& Giessen, L. (2018). Research trend: Forest policy and governance-Future analyses in multiple social science disciplines. Forest Policy and Economics, 91,1-4. https://doi.org/10.1016/ j.forpol.2018.02.007

Nurfatriani, F., Darusman, D., Nurrochmat, D. R., Yustika, A. E., \& Muttaqin, M.Z. (2015). Redesigning Indonesian forest fiscal policy to support forest conservation. Forest Policy and Economics, 61, 39-50. https://doi.org/10. 1016/j.forpol.2015.07.006

Nurrochmat, D. R. (2005). The impacts of regional autonomy on political dynamics, socio-economics and forest degradation. Case of Jambi-Indonesia. Goettingen: Cuvillier Verlag.

Nurrochmat, D. R, Dharmawan, A. H., Obidzinski, K., Dermawan, A., \& Erbaugh J. T. (2016a). Contesting national and international forest regimes: Case of timber legality certification for community forests in Central Java, Indonesia. Forest Policy and Economics, 68, 54-64. https://doi.org/10.1016/j.forpol.2014.09.008

Nurrochmat, D. R., Darusman, D., \& Ekayani, M. (2016b). Kebijakan pembangunan kehutanan dan lingkungan: Teori dan implementasi. Bogor: IPB Press.

Nurrochmat, D. R., Nugroho, I. A., Hardjanto, Purwadianto, A., Maryudi, A., \& Erbaugh, J.T. (2017). Shifting contestation into cooperation: Strategy to incorporate different interest of actors in medicinal plants in Meru Betiri National Park, Indonesia. Forest Policy and Economics, 83, 162-168. https://doi.org/10.1016/ j.forpol.2017.08.005

[PEMKAB Tebo] Pemerintah Kabupaten Tebo. (2017). Rencana pembangunan jangka menengah daerah Kabupaten Tebo Tahun 2017-2022. Tebo: Badan Perencanaan Pembangunan Daerah Kabupaten Tebo.

Putnam, R.D. (1993). The prosperous community social capital and public life. The American Prospect, 4(13).

Ribot, J. C., \& Larson, A. M. (2005). Democratic decentralisation through a natural resource lens. London and New York: Routledge Taylor \& Francis Group.

Rochmayanto, Y., Nurrochmat, D. R., Nugroho, B., Darusman, D., \& Satria, A. (2019). Implementation of REDD + in the existing forest property rights: Lessons from Berau, East Kalimantan Province, Indonesia. IOP Earth and Environmental Science, 285(1). 
Saaty, T. L. (2005). Theory and applications of the analytic network process. Pittsburgh: RWS Publications.

Saaty, T. L., \& Vargas, L. G. (2006). Decision making with the analytic network process, economic, political, social and technological applications with benefits, opportunities, costs and risks. Pittsburgh: University of Pittsburgh.

Sabogal, C., Guariguata, M. R., Broadhead, J., Lescuyer, G., Savilaakso, S., Essoungou, N., \& Sist, P. (2013). Multiple-use forest management in the humid tropics: Opportunities and challenges for sustainable forest management. In: FAO Forestry Paper No. 173, Rome: FAO and CIFOR.

Sahide, M. A. K, Nurrochmat, D. R., \& Giessen, L. (2015). The regime complex for tropical rainforest transformation: Analysing the relevance of multiple global and regional land use regimes in Indonesia. Land Use Policy, 47, 408-425. https://doi.org/10.1016/j.land usepol.2015.04.030

Santoso, S. S., Nurrochmat, D. R., Nugroho, B., \& Santoso, I. (2019). The feasibility of the implementation of forest management units' (FMUS') policy: A case study in FMU Yogyakarta and FMU region IX Panyabungan. Jurnal Manajemen Hutan Tropika, 25(1), 1-16. https://doi.org/ $10.7226 / \mathrm{jtfm} .25 .1 .1$

Sukwika, T., Darusman, D., Kusmana, C., \& Nurrochmat, D. R. (2016). Evaluating the level of sustainablity of privately managed forest in Bogor, Indonesia. Biodiversitas, 17(1), 241-248. https://doi.org/10.13057/ biodiv/d170135

Tampubolon et al. (2018). Toolkits Perencanaan Multiguna Hutan. Pusat Penelitian dan Pengembangan Hutan. Badan Penelitian, Pengembangan, dan Inovasi Kementerian Lingkungan Hidup dan Kehutanan. Bogor.

Wang, S., \& Wilson, B. (2007). Pluralism in the economics of sustainable forest management. Forest Policy and Economics, 9, 743-750. https://doi.org/10.1016/ j.forpol.2006.03.013

World Bank. (2003). Mengupayakan bekerjanya desentralisasi. In: Indonesia Policy Briefs-Ide-Ide Program 100 Hari. Jakarta: Word Bank. 